\title{
In Vitro Evaluation of Isolated Staphylococcal-bacteriophage in Killing Methicillin-Resistant Staphylococcus aureus
}

\section{Orooba Mohammed Saeed Ibrahim ${ }^{1}$, Sarhan Rashid Sarhan ${ }^{1 *}$, Serwa Ibrahim Salih $^{2}$}

\author{
${ }^{1}$ Department of Physiology and Pharmacology, College of Veterinary Medicine, Baghdad University, Iraq; ${ }^{2}$ Depart- \\ ment of Surgery, College of Veterinary Medicine, Baghdad University, Iraq.
}

\begin{abstract}
The present study was carried out to isolate and identified the Staphylococcal-specific bacteriophage from swage water by using agar overlay method and to investigate the anti-Staphylococcal activity of Isolated Bacteriophage in-vitro. Two experiments were performed in this present study; the first one was isolation and identification of Methicillin-Resistant Staphylococcus aureus (MRSA) from post-traumatic bone infection. While the second experiment included study the infectivity of bacteriophage in-vitro to MRSA as well as effect of temperature and $\mathrm{pH}$ on the infectivity of phage was also studied. Results of antimicrobial susceptibility test of S. aureus isolates revealed that most of isolates were resistant to Methicillin, Cefoxitin and Pencillin G. Staphylococcus aureus phage was isolated from sewage samples by agar overlay method, the phage was characterized by clear, circular plaques ranged between $2-3 \mathrm{~mm}$ in diameter. TTA method for determined the Phage MIC appears to be both reliable, and reproducible. This method is laborious and time consuming, and the proposed MIC method appears to be an interesting alternative.
\end{abstract}

Keywords | Methicillin-resistant, Staphylococcus aureus, Bacteriophage_Tetrazolium assay, Bone infection

Editor | Kuldeep Dhama, Indian Veterinary Research Institute, Uttar Pradesh, India.

Received | June 17, 2016; Accepted | September 15, 2016; Published | October 24, 2016

*Correspondence | Sarhan Rashid Sarhan, Department of Physiology and Pharmacology, College of Veterinary Medicine, Baghdad University, Iraq; Email: dr_surhan2000@yahoo.com

Citation | Ibrahim OMS, Sarhan SR, Salih SI (2016). In vitro evaluation of isolated Staphylococcal-bacteriophage in killing methicillin-resistant Staphylococcus aureus. Adv. Anim. Vet. Sci. 4(10): 550-562.

DOI | http://dx.doi.org/10.14737/journal.aavs/2016/4.10.550.562

ISSN (Online) | 2307-8316; ISSN (Print) | 2309-3331

Copyright (c) 2016 Ibrahim et al. This is an open access article distributed under the Creative Commons Attribution License, which permits unrestricted use, distribution, and reproduction in any medium, provided the original work is properly cited.

\section{INTRODUCTION}

$\mathrm{M}$ RSA stands for Methicillin-resistant Staphylococcus aureus, a type of $S$. aureus that has become resistant to certain antibiotics such as methicillin, penicillin, amoxicillin, and is thus more difficult to treat. MRSA often lives on the skin or in the nose of healthy people without causing symptoms (this is called colonization). It can, however, cause skin and other infections. Most infections are minor, such as pimples and boils. Serious infections such as wound infections, pneumonia, or septicaemia (infections getting into the bloodstream) can result in life-threatening illness or, on rare occasions, death, if left untreated. Those with weakened immune systems and chronic illnesses are more susceptible to developing an infection (PICNet, 2015).

Penicillin disrupts the cross-linking of small peptide chains in peptidoglycans during the production of bacteri- al cell walls (Yocum et al., 1979; Anonymous, 2012). As a result, pre-existing cells are unaffected, but newly produced bacteria are unable to maintain their cell-wall rigidity and ultimately undergo lysis. Within ten years of the widespread use of penicillin, Staph. aureus had developed resistance by producing penicillinase, an enzyme which cleaves the penicillin beta-lactam ring. To combat this resistance, a semisynthetic class of penicillins (e.g. methicillin) was introduced in the 1960s. Methicillin had an additional acyl-group on the beta-lactam ring which conferred a high degree of resistance to penicillinase and produced broader antibacterial activity against some Gram-negative bacteria. Methicillin resistance developed in Staph. aureus at a slower pace than the initial resistance to penicillin (Chambers et al., 2001). Penicillin and its derivatives, including methicillin have been used for the treatments of infections caused by S. aureus (Rayner and Munckhof, 2005). Less than $90 \%$ of $S$. aureus strains are resistant to most penicil- 
lin derivatives (Chambers et al., 2001; Freeman-Cook and Freeman-Cook, 2006) and ordinary antimicrobial agents like drugs from the family of aminoglycosides, macrolides, chloramphenicols, tetracyclines and fluoroquinolones (Lee, 2003).

Expression of an alternative penicillin-binding protein, PBP2a conferred resistance and rendered the entire antibiotic class ineffective. This is encoded on the methicillin-resistance gene mec A, which is a component of a highly mobile genetic element known as the staphylococcal cassette chromosome (SCC) (Enright et al., 2002; Wielders et al., 2002). MRSA isolates from hospital settings has been gradually increasing in the United States and other parts of the world. Depending on the study area and sample size, high rate of MRSA rates (>50\%) have been reported in USA, Asia and Malta, intermediate rate (25$50 \%$ ) reported in Africa, China and Europe while in some part of Europe, the prevalence rate is relatively lower than 50\% (Mejìa et al., 2010).

Stafeni et al. (2012) compiled the prevalence rates of HA-MRSA in some European countries like France, Ireland and UK and reported decline in hospital cases. While in Asia particularly South Korea (77.6\%), Vietnam (74.1\%), Taiwan (65\%) and Hong Kong (56.8\%) reports on HA-MRSA infections is still high (A1-Dahbi and A1-Mathkhury, 2013), the incidence of MRSA among $S$. aureus was 94.3\%. Babakir-Mina et al. (2012) found that among S. aureus positive cases, $88 \%$ were MRSA. A1Hasani (2005) indicated that 41/49 (83.7\%) were MRSA.

Muhammad and Al-Mathkhury (2014) found that among S. aureus positive cases, $65 \%$ were MRSA. Another study done in Basra university, Nursing college by Al-Mussawi (2014) stated that 17 (65\%) from 26 isolates were MRSA.

Animals such as dogs, cats and horses have become an important part of most families particularly in developed countries like USA and UK (Chomel and Sun, 2011). In the UK, $1.5 \%$ of MRSA were recovered from samples of infected companion animals (Rich and Roberts, 2004) and dogs are more infected/colonized with MRSA in comparism to cats (Morgan, 2008). Reports of MRSA colonization in horses with a percentage rate of 0 to $11 \%$ has been published. Most cases and outbreak of MRSA infections were reported in large stables and post-operative complications (Weese et al., 2005; Morgan, 2008).

During the last 30 years, no new classes of antibiotics have been found, even with the help of modern biotechnology such as genetic engineering. Pharmaceutical companies have mainly focused on the development of new products derived from the known classes of antibiotics (Sulakvelidze et al., 2001) which is a cause of major concern. Thus, ex- ploring alternative approaches to develop antibacterial products is also a worthwhile task, and re-examining the potential of promising older methods might be of value. One of the possible replacements for antibiotics is the use of bacteriophages or simply phages as antimicrobial agents (Shasha et al., 2004; Vinodkumar et al., 2008).

Phage therapy involves the use of lytic phages for the treatment of bacterial infections, especially those caused by antibiotic resistant bacteria. In general, there are two major types of phages, lytic and lysogenic. Only the lytic phages (also known as virulent phages) are a good choice for developing therapeutic phage preparations (Sandeep, 2006; Borysowski and Gorski, 2008). The bactericidal ability of phages has been used to treat human infections for years as a complement or alternative to antibiotic therapy (Alisky et al., 1998; Matsuzaki et al., 2005; Kysela and Turner, 2007).

Bacteriophages, nature's tiniest viruses and it is estimated that there are about 1031 phages on earth making viruses the most abundant life form on earth (Ashelford et al., 2000; Hendrix, 2002; Dabrowska et al., 2005). Bacteriophages do not only help in the treatments of bacterial infections in animals and human beings but also used in birds, fishes, plants, food material and biofilm eradication (Flaherty et al., 2000; Goode et al., 2003; Leverentz et al., 2003; Park and Nakai, 2003; Curtin and Donlan, 2006).

\section{MATERIALS AND METHODS}

\section{ISOLATION AND IDENTIFICATION}

50 samples of pus were taken from patient suffering from post-traumatic bone infection. All patient who were suspected to had Staphylococcal infections. Culture specimens were obtained at the time of admission, after the surface of the wound had been washed vigorously by saline, and followed by debridement of superficial exudates. Pus was collected by sterile syringe. Specimens were promptly took to the laboratory and processed. Standard methods for isolation and identification of $S$. aureus were used (Sowmya et al., 2014) (Table 1).

Table 1: Morphological and biochemical tests to S. aureus

$\begin{array}{lll}\text { Bacterial spp. } & \begin{array}{l}\text { Morphological } \\ \text { examination }\end{array} & \text { Biochemical tests } \\ \text { S. aureus } & \begin{array}{l}\text { Gram stain } \\ \text { Staph } 110 \text { agar }\end{array} & \begin{array}{l}\text { Mannitol salt agar } \\ \text { Catalase test }\end{array} \\ & \begin{array}{l}\text { Blood agar } \\ \text { Motility test }\end{array} & \begin{array}{l}\text { Coagulase test } \\ \text { Oxidase test }\end{array} \\ \end{array}$

\section{Detection of Methicillin Resistant}

The isolates of $S$. aureus were subjected to cefoxitin, methicillin and penicillin G Discs (Bioanalyse, Turkey), using a $30 \mu \mathrm{g}, 10 \mu \mathrm{g}$ and $10 \mathrm{U}$ disc respectively. A $0.5 \mathrm{McF}$ arland 
standard suspension of the isolate $\left(1.5 \times 10^{8} \mathrm{PFU} / \mathrm{ml}\right)$ was made and lawn culture was done on Muller-Hinton agar, (Oxoid-England) plate. Plates were incubated at $37^{\circ} \mathrm{C}$ for $18 \mathrm{hr}$. and zone diameters were measured (Table 2) (EUCAST, 2009; CLSI, 2012).

\section{IsOlation AND Purification OF $S$. aureus}

BACTERIOPHAGE

Sample Collection: The methods used adapted from (USEPA, 2001; Jaime and Tiffany, 2003). $45 \mathrm{ml}$ raw sewage was measured into graduated cylinder, the sample centrifuged at $3500 \mathrm{rpm}$ for $15 \mathrm{~min}$, the supernatant is filtered through $0.22 \mu \mathrm{m}$ Millipore filter and decanted into Erlenmeyer flask and pipette $5 \mathrm{ml}$ double sterile phosphate buffer saline and $5 \mathrm{ml}$ Staphylococcus aureus suspension (1.5 $\times 10^{8} \mathrm{cfu} / \mathrm{ml}$ ), then incubated at $37^{\circ} \mathrm{C}$ for 24 hours.

Phage Isolation: Isolation of phage and seeding by using agar overlay technique (Dias et al., 2013). Sewage and $S$. aureus culture distributed into 8 centrifuge tubes and centrifuged the sample at 2000 RPM for 5 minute. Most of the remaining cells was pelleted. The supernatant contains bacteriophage pipetted into a Millipore filter $(0.22 \mu \mathrm{m})$ and until all the liquid is pulled into the container, then $0.1 \mathrm{ml}$ of filtrate and $0.1 \mathrm{ml}$ of $S$. aureus added to $3 \mathrm{ml}$ of top agar, then mixed and poured over a plate of bottom agar, the plate allowed to be harden, invert the plate and incubate at 37 ${ }^{\circ} \mathrm{C}$ for 24 hours and then phage plaque detected. Top and Bottom agars were prepared according to (Sanders, 2012).

Preperation, Standard of Phage Suspention Stock and Storage of Bacteriophage: When plaques were identified, a pure suspension is prepared by carefully removing a portion of the phage single plaque on bottom agar plate by stabbing the center of a plaque with a sterile needle. Rinse in $10 \mathrm{ml}$ sterile TSB (Tryptic Soya Broth, Hi-media-India), the broth is transferred to a sterile $25 \mathrm{ml}$ centrifuge tube and centrifuging at $5000 \mathrm{rpm}$ for $5 \mathrm{~min}$. The supernatant filter through 0.22 micro-filter and then aseptically transferred to a sterile $15 \mathrm{ml}$ tube and stored at $4{ }^{\circ} \mathrm{C}$ till use. (Dias et al., 2013; Maier et al., 2000).

\section{Determination of Phage Typing to $S$. aureus by USING Spot TesT}

The type of phage strain will determine using an isolate of $S$. aureus. Two microliters of concentrated phage lysate $\left(10^{8}\right.$
$\mathrm{PFU} / \mathrm{ml}$ ) then dropped onto a NA (Nutrient agar, Oxoid-England), plate overlaid with $\mathrm{S}$. aureus and incubate overnight. The lytic ability of phage isolates assessed using the clarity of plaques (Stenholm et al., 2008).

\section{Measurement of Phage Titer PFU/ml by using} Phage Plague Assay

Ten-fold serial dilutions to $10^{-9}$ of phage filtrate made in PBS. $3 \mathrm{ml}$ of hot, melted top agar into three $13 \times 100 \mathrm{~mm}$ test tubes held in $47^{\circ} \mathrm{C}$ water bath. To each tube of $47^{\circ} \mathrm{C}$ top agar, $0.1 \mathrm{ml}$ of $S$. aureus added and $0.1 \mathrm{ml}$ of the 108 phage dilution quickly pipited into a tube of top agar containing host bacteria, mix well but gently to avoid bubbles and quickly pour the mixture onto the surface of bottom agar while turning the dish with the left hand, tap out the final drop, the plates rapidly tilted and distributed over the surface of the bottom layer, this procedure was repeated with others phage dilutions. The top agar allow to solidify and become firmly attached to the hard agar bottom, all the plates inverted and incubated for $24 \mathrm{hrs}$. The phage titer determined by counting the number of plaque forming units (p.f.u.) for each dilution. For determination (dilution factor) that used for all other experiments. Plate that had between 30 and 300 plaques were counted by applying the following formula (Anderson et al., 2011).

$$
\text { Phage titer }=\frac{\text { Number of plagues }}{\text { Dilution factor X Plating amount }}
$$

\section{Effect of Temperature and $\mathrm{pH}$ on the}

\section{Infectivity of Phage}

$\mathrm{pH}$ values of 2, 7.4 and 8 were used to determine whether the bacteriophages are affected by exposure to different $\mathrm{pH}$ values. The values were chosen in accordance with the range of $\mathrm{pH}(2-8)$ obtained in Rabbit GIT. Triplicate tubes are prepare with $9.9 \mathrm{ml}$ of different buffer solution; buffer $\mathrm{A} \mathrm{pH}=2(50 \mathrm{ml}$ of $0.2 \mathrm{M} \mathrm{KCL}+13 \mathrm{ml}$ of $0.2 \mathrm{M} \mathrm{HCL})$, buffer $\mathrm{B} \mathrm{pH}=7.4(100 \mathrm{ml}$ of $0.1 \mathrm{M} \mathrm{KH} 2 \mathrm{PO} 4+78.2 \mathrm{ml}$ of $0.1 \mathrm{M} \mathrm{NaOH})$ and buffer $\mathrm{C} \mathrm{pH}=8(100 \mathrm{ml}$ of $0.1 \mathrm{M} \mathrm{KH}-$ $2 \mathrm{PO} 4+93.4 \mathrm{ml}$ of $0.1 \mathrm{M} \mathrm{NaOH})(\mathrm{BDH}$, England) will add to a total volume of $10 \mathrm{ml}\left(0.1 \mathrm{ml}\right.$ of $3 \times 10^{8}$ phage) . Then, $0.1 \mathrm{ml}$ samples were taken with regular intervals (sampling begins at the first $1 \mathrm{~h}, 6 \mathrm{~h}$, and $12 \mathrm{~h}$ ) and added $S$. aureus culture. Plaque assays were performed for each sample to register the change in abundance of infectious phages over time.

Table 2: Antimicrobial susceptibility testing standards (EUCAST, 2009; CLSI, 2012)

\begin{tabular}{lllll} 
Antibiotic discs & \multicolumn{2}{l}{ Disc concentration } & \multicolumn{4}{l}{ Diameter of inhibition zone (mm) Interpretive criteria } \\
\cline { 3 - 5 } & & Resistant (R) & Intermediate (I) & Sensitive (S) \\
Cefoxitin & $30 \mu \mathrm{g}$ & $\leq 21$ & - & $\geq 22$ \\
Methicillin & $10 \mu \mathrm{g}$ & $\leq 9$ & $10-13$ & $\geq 14$ \\
Penicillin G & $10 \mathrm{U}$ & $\leq 28$ & - & $\geq 29$ \\
\hline
\end{tabular}




\section{OPEN $\odot$ ACCESS}

Optimal phage dilution prepares using saline and placed in a $40{ }^{\circ} \mathrm{C}, 50{ }^{\circ} \mathrm{C}$ and $60{ }^{\circ} \mathrm{C}$ water bath and $37^{\circ} \mathrm{C}$ as a control. $0.1 \mathrm{ml}$ of phage dilution then remove after 10, 20, 30, 40, 50, and $60 \mathrm{~min}$ had elapsed and added to sloppy agar previously inoculated with Staph aureus culture then plated on NA and incubated overnight at each temperature the number of p.f.u. were determined for each time interval (Al-khafaji, 2012; Madsen et al., 2013).

\section{Minimum InHibitory CONCENTRATION BACTERIOPHAGE AGAINST MRSA}

The MICs of phages was determined by using the tetrazolium salt in the tube dilution assay and this method was modified from Vipra et al. (2013), standard bacterial suspension $\left(1.5 \times 10^{8} \mathrm{cfu} / \mathrm{ml}\right)$ adjusted to $0.5 \mathrm{McFarland}$ tube was added to the 9 tubes containing $6 \mathrm{ml}$ nutrient broth. The phage preparations were diluted to contain different concentration of phages, (Ranging from $10^{-1}$ to $10^{-9}$ ) pfu/ $\mathrm{ml}$, and $1 \mathrm{ml}$ of phage dilutions were added to all tubes containing bacterial cells. Corresponding cell control, phage control and media control were maintained. After $24 \mathrm{~h}$ incubation $35^{\circ} \mathrm{C}$ without shaking to visually differentiate between the live and dead cells, $200 \mu \mathrm{L}$ of TTA reagent was added to each tube and observed for colour development after $2 \mathrm{hr}$. The lowest concentration of phage at which no colour was seen was regarded as the MIC.

\section{Statistical Analysis}

Data were analyzed statistically using the Microsoft Program, SAS (Statistical Analysis System - version 9.1). Sta- tistical analysis of data was performed on the basis of TwoWay Analysis of Variance (ANOVA) using a significant level of $(\mathrm{P}<0.05)$. Post hoc test was performed to assess significant difference among means.

\section{RESULTS}

\section{ISOLATION AND IDENTIFICATION}

The results of isolation and culturing of bacteria including biochemical tests showed that a total of 50 pus samples which were collected from patients suffering from post-traumatic bone infection, 42 samples, showed positive results for the presence of Staphylococcus aureus (Table 3).

Table 3: Prevalence of Staphylococcus aureus from the collected samples

\begin{tabular}{|lll|}
\hline Bacteria & No. of samples & Percentage \% \\
\hline S. aureus & 42 & $84 \%$ \\
\hline Other & 8 & $16 \%$ \\
\hline Total & 50 & $100 \%$ \\
\hline
\end{tabular}

\section{Morphological Examination and Culture}

\section{Characteristics}

The suspected bacteria was cultured on Blood agar, Mannitol salt agar and Staph 110 and after purification of bacteria, biochemical tests (Catalase, Coagulase, and Oxidase tests) were done as well as gram staining was performed, 42 samples showed positive results for the presence of Staphylococcus aureus. Results shown in Table 4,5 and Figure 1.

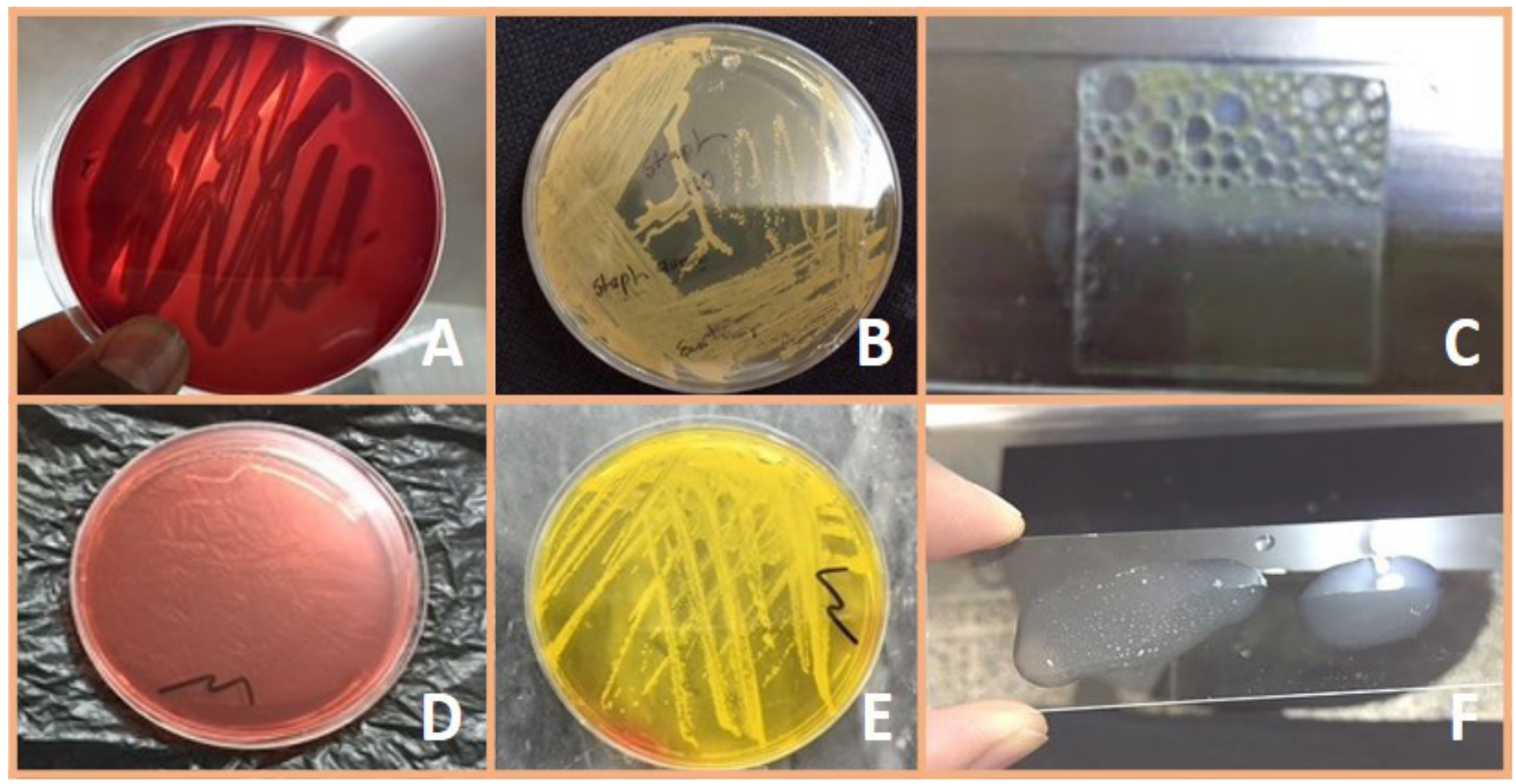

Figure 1: A) Staph aureus on blood agar ( $\beta$ - Hemolysis); B) Staph. aureus on Staph 110 agar (Creamy to yellow or orange); C) Positive catalase test; D) Mannitol salt agar without $S$. aureus culture; E) Fermentation of mannitol salt agar by $S$. aureus. (Formation of yellow color colony); F) Positive coagulase test 
Table 4: Morphological tests used to identify Staphylococcus aureus

\begin{tabular}{ll} 
Morphological tests & Results \\
Gram stain & G +ve cocci \\
Staph 110 agar & Creamy to yellow or orange colonies \\
Blood agar & $\begin{array}{l}\text { Golden yellow, round, smooth colo- } \\
\text { nies. } \beta \text {-Hemolysis }\end{array}$ \\
\hline
\end{tabular}

Table 5: Biochemical tests used to identify Staphylococcus aureus

\begin{tabular}{|c|c|}
\hline Biochemical tests & Results \\
\hline Mannitol salt agar & $\begin{array}{l}\text { Conversion of medium from } \\
\text { rosy to yellow }\end{array}$ \\
\hline Catalase test & Formation of gas bubble \\
\hline Coagulase Test (Slide method) & Clumping appeared \\
\hline Oxidase test & $\begin{array}{l}\text { (no purple colour appeared ), } \\
\text { negative result }\end{array}$ \\
\hline
\end{tabular}

\section{Detection of Methicillin Resistant $S$. aureus by} using Disc Diffusion Method

After the identification of $S$. aureus, susceptibility test was done for all $S$. aureus isolates by disk diffusion method to detect the presence of MRSA (Figure 2), according to National Committee for Clinical Laboratory Standards guidelines recommendation (NCCLS) (Table 6).

Table 6: Antibiotic sensitivity test of S. aureus

\begin{tabular}{llllllll} 
Bacteria & \multicolumn{6}{l}{ Staphylococcus aureus } & $(\mathbf{n}=42)$ \\
Antibiotic & R & & I & & S & \\
discs & No & $\%$ & No & $\%$ & No & $\%$ \\
Cefoxitin $30 \mu \mathrm{g}$ & 39 & 92.85 & - & - & 3 & 7.15 \\
Methicillin 10 $10 \mathrm{~g}$ & 40 & 95.23 & - & - & 2 & 4.77 \\
Penicillin G 10 U & 42 & 100 & - & - & - & -
\end{tabular}

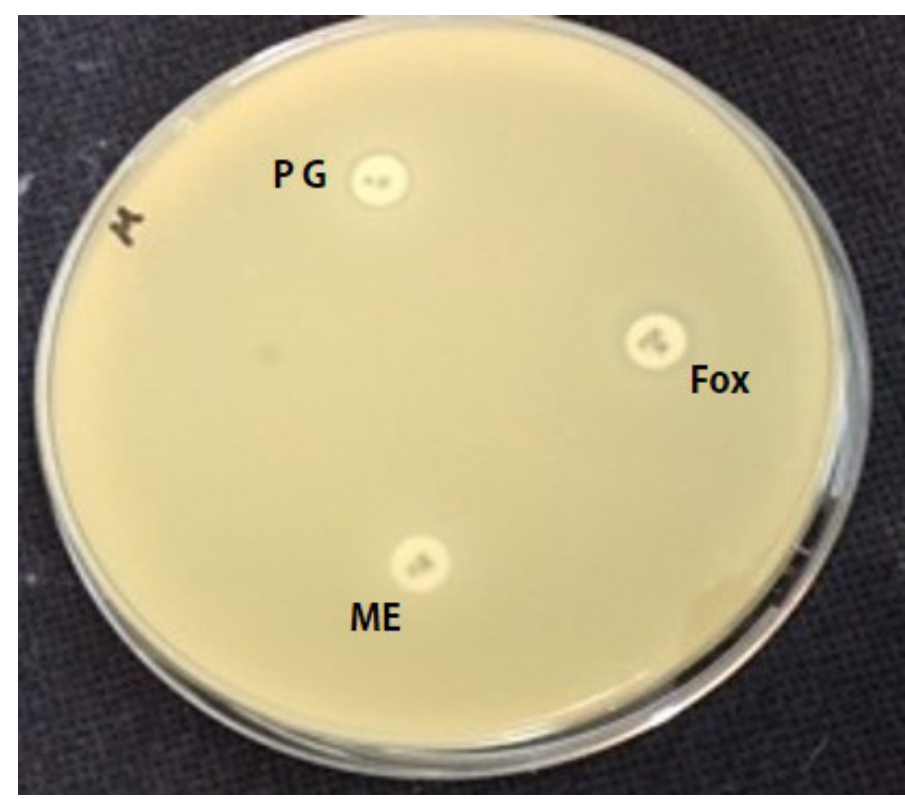

Figure 2: Antibiotic sensitivity of S. aureus showed MRSA
Results of antibacterial sensitivity test of Staphylococcus aureus shown that all isolates were resistance to penicillin $100 \%$, this may explain why $S$. aureus is totally resistant to pencillin G. Also it was found that $92.85 \%$ were resistant to cefoxitin and $95.23 \%$ of S. aureus were resistant to methicillin.

\section{Isolation AND PURIFICATION OF $S$. aureus}

BACTERIOPHAGE

Sample Collection: Staph aureus specific- Bacteriophage associated with osteomyelitis which had been separated from sewage water near to the hospital Lab and Surgery Theatre through agar method. Phage were able to lyse bacteria and form plaques after incubation $24 \mathrm{hr}$ at $37^{\circ} \mathrm{C}$. A piece of single plaque of phage on the bottom agar were picked by sterile needle put in broth for $3 \mathrm{hrs}$ and re-infect the host to confirm obtaining phage (Figure 3).

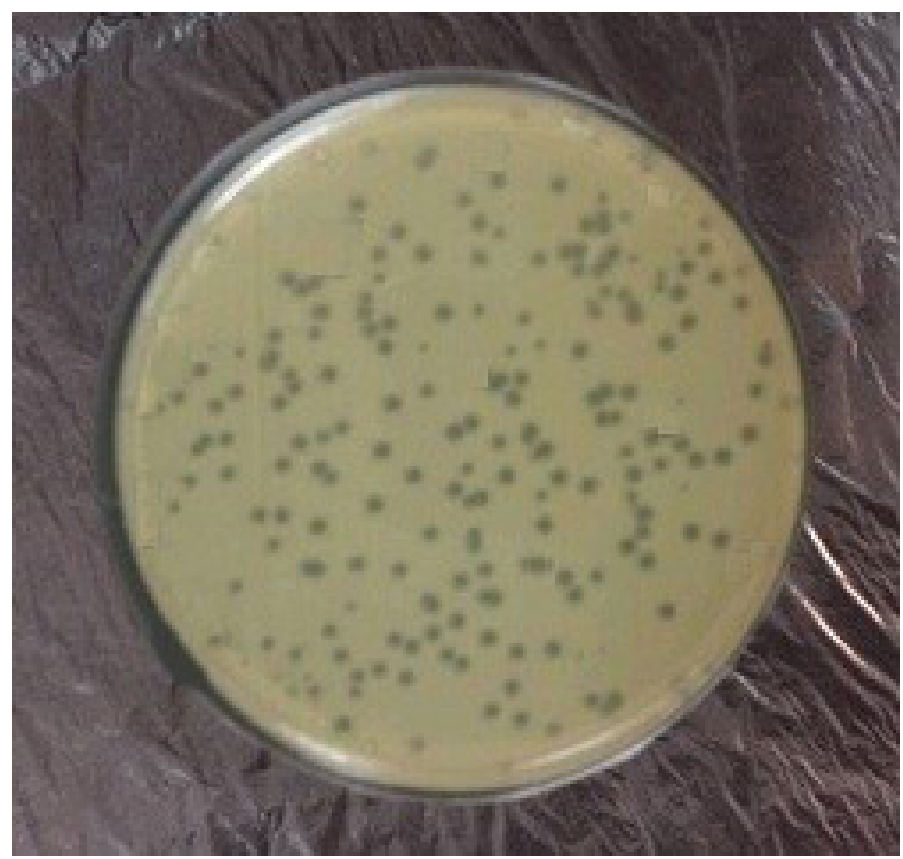

Figure 3: Plaques formed after 24 hrs incubation on MRSA culture

Plaque Morphology: Plaques were formed as clear circular with a size ranged between $2-3 \mathrm{~mm}$ in diameter when incubated at $37^{\circ} \mathrm{C}$ for $24 \mathrm{hrs}$,

\section{Preparation of Phage Stock and Titration}

Overlay technique was used to prepare of Staph aureus phage stock solution and a titer between 101 to 109 PFU/ $\mathrm{ml}$ was made. Calculation of phage titer by using Series of dilutions were used to calculation of phage titer and the p.f.u. for each dilution are $\left(5.8 \times 10^{4}, 5.4 \times 10^{5}, 4.3 \times 10^{6}\right.$, $4.0 \times 10^{7}, 3.0 \times 10^{8}, 2.5 \times 10^{9}, 2.1 \times 101^{0}, 1.8 \times 10^{11}$ and $\left.1.2 \times 10^{12}\right)$, respectively. Dilution factor that gave the best countable number of plaques is $\left(10^{5}\right)$, this dilution factor was then used for all other experiments and the $\mathrm{pfu} / \mathrm{ml}$ was $\left(3 \times 10^{8}\right)$, (Table 7). In addition the optical density of all dilutions were recorded at the same time. 
OPEN OACCESS

Table 7: Determination of $S$. aureus phage titer

\begin{tabular}{|llll} 
Plate No. & $\begin{array}{l}\text { Plaque } \\
\text { per plate }\end{array}$ & TTA $^{*}$ & $\begin{array}{c}\text { Titer Plaque } \\
\text { forming unit }\end{array}$ \\
\hline 1 & 580 & $580 \times 10^{1} / 0.1$ & $5.8 \times 10^{4}$ \\
\hline 2 & 540 & $540 \times 10^{2} / 0.1$ & $5.4 \times 10^{5}$ \\
\hline 3 & 430 & $430 \times 10^{3} / 0.1$ & $4.3 \times 10^{6}$ \\
\hline 4 & 400 & $400 \times 10^{4} / 0.1$ & $4.0 \times 10^{7}$ \\
\hline 5 & 300 & $300 \times 10^{5} / 0.1$ & $3.0 \times 10^{8}$ \\
\hline 6 & 250 & $250 \times 10^{6} / 0.1$ & $2.5 \times 10^{9}$ \\
\hline 7 & 210 & $210 \times 10^{7} / 0.1$ & $2.1 \times 10^{10}$ \\
\hline 8 & 180 & $180 \times 10^{8} / 0.1$ & $1.8 \times 10^{11}$ \\
\hline 9 & 120 & $120 \times 10^{9} / 0.1$ & $1.2 \times 10^{12}$ \\
\hline *: Titer calculation $=$ Plaque $\times \mathrm{DF} /$ Volume of phage plated $(\mathrm{ml})$
\end{tabular}

Determination of Host Range (Phage Typing) Specifity of bacteriophage to MRSA was determined by using Spot lysis technique, MRSA are efficiently lysed by specific bacteriophage. Clear lyses zone was formed and bacterial growth inhibited at the point of phage dropped Approving these Staph. aureus isolates have particular receptor on its cell wall for phage attachment (Figure 4).

\section{Minimum InHibitory Concentration of} BACTERIOPHAGE AGAINST MRSA

The MIC of phage was the dilution $10^{-7}\left(1.2 \times 10^{10}\right)$ (Figure 5). TTAs basically depend on reduction of tetrazolium to a reduced substance called formazan in mammalian cells and this test have been used to differentiate between the live and dead bacterial cell because only live bacteria convert the tetrazolium to purple formazan. We adopted this method to estimate the MIC of phages.

Effect of Temperature and pH ON The Infectivity of Phage

$\mathrm{pH}$ values of $2,7.4$ and 8 used to estimate if the bacteriophages are influenced by exposure to various $\mathrm{pH}$ values. These different values were selected according to the range
Advances in Animal and Veterinary Sciences of $\mathrm{pH}$ (2-8) found in Rabbit GIT (Table 8). PFU were measured for every specimen to record the change in the infectivity phages over time in different $\mathrm{pH}$.

Table 8: Change in infectivity of the Bacteriophage (mean $\log _{10}$ of phage concentration $\mathrm{PFU} / \mathrm{ml}$ ) over time at different $\mathrm{pH}$ values

\begin{tabular}{|c|c|c|c|c|}
\hline \multirow[t]{2}{*}{$\begin{array}{l}\text { Time } \\
\text { (hr) }\end{array}$} & \multirow[t]{2}{*}{$\begin{array}{l}\text { Dilution } \\
\text { factor }\end{array}$} & \multicolumn{3}{|c|}{$\begin{array}{l}\text { Titer: plaque forming unit (mean } \\
\log _{10} \text { PFU/ml) at different } \mathrm{pH} \text { values }\end{array}$} \\
\hline & & $\mathrm{pH} 2$ & $\mathrm{pH} 7.4$ & pH 8 \\
\hline 1 & $10^{5}$ & $\begin{array}{l}6.77 \pm 0.07 \\
\mathrm{~B} \mathrm{a}\end{array}$ & $\begin{array}{l}8.25 \pm 0.04 \\
\mathrm{~A} \mathrm{~b}\end{array}$ & $\begin{array}{l}8.17 \pm 0.06 \\
\mathrm{~A} \mathrm{~b}\end{array}$ \\
\hline 6 & $10^{5}$ & $\begin{array}{l}6.30 \pm 0.03 \\
\mathrm{~B} \mathrm{~b}\end{array}$ & $\begin{array}{l}8.36 \pm 0.02 \\
\mathrm{~A} \mathrm{~b}\end{array}$ & $\begin{array}{l}8.44 \pm 0.07 \\
\text { A a }\end{array}$ \\
\hline 12 & $10^{5}$ & $\begin{array}{l}0.0 \pm 0.0 \\
\mathrm{Cc}\end{array}$ & $\begin{array}{l}8.5 \pm 0.05 \\
\mathrm{~A} \mathrm{a}\end{array}$ & $\begin{array}{l}8.0 \pm 0.02 \\
\mathrm{~B} \mathrm{c}\end{array}$ \\
\hline
\end{tabular}

Values represent mean \pm S.E; LSD: 0.1359; Different capital letters mean significant $(\mathrm{P}<0.05)$ results between different $\mathrm{pH}$ values; Different small letters mean significant $(\mathrm{P}<0.05)$ results between different hours

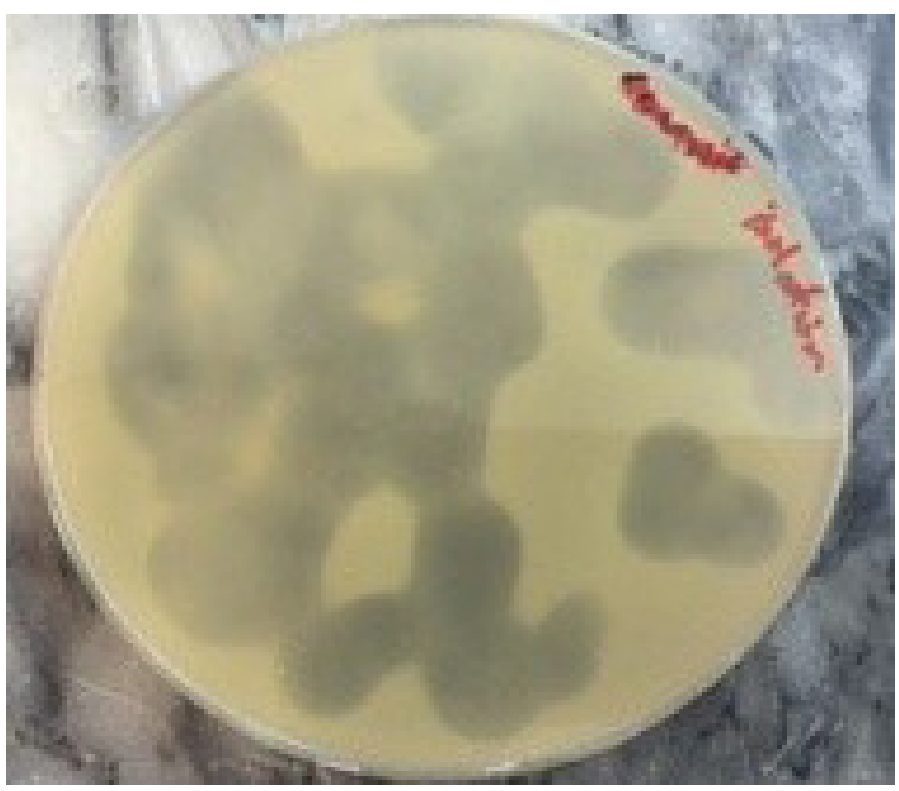

Figure 4: Spot lysis test after 24 hrs incubation

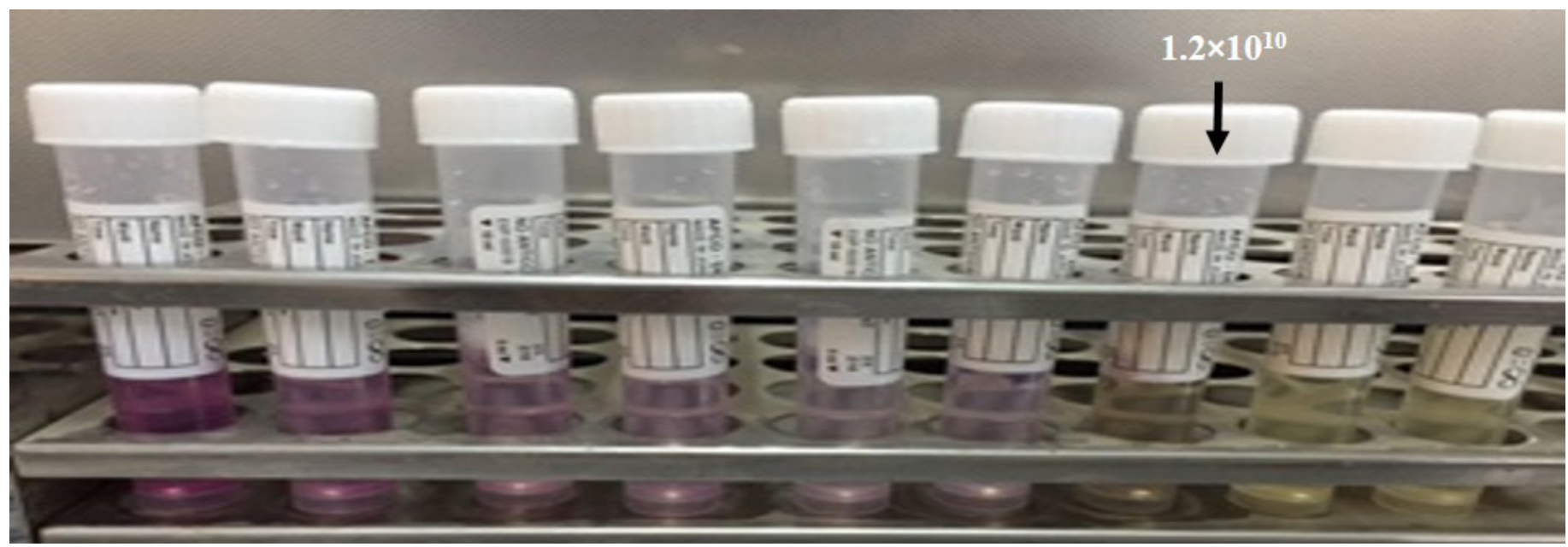

Figure 5: Minimum inhibitory concentration of bacteriophage against MRSA 
Table 9: Sensitivity determination of staph aurous phage titer (mean $\log _{10}$ of phage concentration $\mathrm{PFU} / \mathrm{ml}$ ) in relation to different degrees of temperature

\begin{tabular}{llllll} 
Time (min) & Dilution factor & \multicolumn{5}{l}{ Titer: plaque forming unit (mean $\mathbf{L o g}_{\mathbf{1 0}} \mathbf{P F U} \mathbf{m l )}$} \\
& & $\mathbf{3 7}{ }^{\circ} \mathrm{C}$ & $\mathbf{4 0}{ }^{\circ} \mathrm{C}$ & $\mathbf{5 0} \mathbf{C}$ & $\mathbf{6 0}{ }^{\circ} \mathbf{C}$ \\
10 & $10^{5}$ & $8.37 \pm 0.08 \mathrm{~A} \mathrm{a}$ & $8.29 \pm 0.12 \mathrm{~A} \mathrm{a}$ & $8.11 \pm 0.13 \mathrm{~A} \mathrm{a}$ & $0.0 \pm 0.0 \mathrm{~B} \mathrm{a}$ \\
20 & $10^{5}$ & $8.44 \pm 0.11 \mathrm{~A} \mathrm{a}$ & $8.39 \pm 0.15 \mathrm{~A} \mathrm{a}$ & $7.69 \pm 0.12 \mathrm{~B} \mathrm{~b}$ & $0.0 \pm 0.0 \mathrm{C} \mathrm{a}$ \\
30 & $10^{5}$ & $8.50 \pm 0.09 \mathrm{~A} \mathrm{a}$ & $8.44 \pm 0.06 \mathrm{~A} \mathrm{a}$ & $0.0 \pm 0.0 \mathrm{~B} \mathrm{c}$ & $0.0 \pm 0.0 \mathrm{~B} \mathrm{a}$ \\
40 & $10^{5}$ & $8.57 \pm 0.11 \mathrm{~A} \mathrm{a}$ & $8.44 \pm 0.08 \mathrm{~A} \mathrm{a}$ & $0.0 \pm 0.0 \mathrm{~B} \mathrm{c}$ & $0.0 \pm 0.0 \mathrm{~B} \mathrm{a}$ \\
50 & $10^{5}$ & $8.68 \pm 0.18 \mathrm{~A} \mathrm{a}$ & $8.60 \pm 0.05 \mathrm{~A} \mathrm{a}$ & $0.0 \pm 0.0 \mathrm{~B} \mathrm{c}$ & $0.0 \pm 0.0 \mathrm{~B} \mathrm{a}$ \\
60 & $10^{5}$ & $8.68 \pm 0.13 \mathrm{~A} \mathrm{a}$ & $8.62 \pm 0.04 \mathrm{~A} \mathrm{a}$ & $0.0 \pm 0.0 \mathrm{~B} \mathrm{c}$ & $0.0 \pm 0.0 \mathrm{~B} \mathrm{a}$
\end{tabular}

Values represent mean \pm S.E; LSD: 0.3412; Different capital letters mean significant $(\mathrm{P}<0.05)$ results between different temperature; Different small letters mean significant $(\mathrm{P}<0.05)$ results between minutes

The aim of this experiment was to test the staph aureus specific-bacteriophage degradation and survival in different $\mathrm{pH}$ environment that influenced the decay rates of phage and the infectivity of the bacteriophage. There was no significant decrease in bacteriophage infectivity to lyse the bacteria during the $6 \mathrm{hr}$ incubation at $\mathrm{pH} 7.5$ and 8 , and the $\mathrm{pfu} / \mathrm{ml}$ was $2.3 \times 10^{8}$, mean $\log 10$ (8.36), $2.8 \times 10^{8}$ (8.44), respectively. This is approved that there are no significant differences $(\mathrm{P}<0.05)$ between these two $\mathrm{pH}$ values during the first $6 \mathrm{hr}$., but there are a significant differences $(\mathrm{P}<0.05)$ between the phage titer at $\mathrm{pH} 7$ and $\mathrm{pH} 8$ in comparison with phage titer at $\mathrm{pH} 2$. While the pfu at $\mathrm{pH}$ 8 was decrease slightly to $1.0 \times 10^{8}$ after $12 \mathrm{hr}$. bacteriophage lost its infectivity when incubated at $\mathrm{pH} 2$ between ( $1 \mathrm{hr}-6 \mathrm{hr}$ ) incubation from $0.6 \times 10^{8}(6.77$ mean $\log 10)$ to $0.2 \times 10^{8}(6.30$ mean $\log 10)$ and the pfu became 0.0 after $12 \mathrm{hr}$ incubation at $\mathrm{pH} 2$.

Ideal phage dilution prepared with normal saline and put in graded temperatures $40^{\circ} \mathrm{C}, 50^{\circ} \mathrm{C}$ and $60{ }^{\circ} \mathrm{C}$ and $37^{\circ} \mathrm{C}$ as a control. $0.1 \mathrm{ml}$ of phage sample were taken after 10 $\mathrm{min}, 20 \mathrm{~min}, 30 \mathrm{~min}, 40 \mathrm{~min}, 50 \mathrm{~min}$, and $60 \mathrm{~min}$ incubation in these temperatures and then overnight culture of staph aureus added. PFU were measured using double layer technique for each time. And phage titer $\mathrm{pfu} / \mathrm{ml}$ and mean $\log 10$ during $10,20,30,40,50$, and 60 minutes was $2.3 \times 10^{8}(8.37), 2.8 \times 10^{8}(8.44), 3.2 \times 10^{8}(8.5), 3.8 \times 10^{8}$ (8.57), $4.3 \times 10^{8}(8.68)$ and $4.8 \times 10^{8}(8.68)$, respectively in the temperature $37 \mathrm{C}^{\circ}$ and phage titer mean $\log 10$ was $1.9 \times 10^{8}(8.29), 2.5 \times 10^{8}$ (8.39), $2.8 \times 10^{8}$ (8.44), $2.8 \times 10^{8}$ (8.44), $3.0 \times 10^{8}(8.60)$ and $3.3 \times 10^{8}(8.62)$, respectively in the temperature $40{ }^{\circ} \mathrm{C}$. The phage titer and mean $\log 10$ was $(1.3 \times 108$ (8.11), $0.8 \times 108$ (7.69), 0.0, 0.0, 0.0 and 0.0), respectively in the temperature $50{ }^{\circ} \mathrm{C}$. While the phage titer and mean $\log 10$ was $(0.0,0.0,0.0,0.0,0.0$ and 0.0$)$, respectively in the temperature $60{ }^{\circ} \mathrm{C}$ (Table 9).

The statistical analysis results showed significant increase $(\mathrm{P}<0.05)$ in phage titer in temperature $37^{\circ} \mathrm{C}$ and $40^{\circ} \mathrm{C}$ comparing with phage titer in temperature $50^{\circ} \mathrm{C}$ and $60^{\circ} \mathrm{C}$.

Most of the bacteriophage were sensitive to temperatures above $50^{\circ} \mathrm{C}$ and inactivated instantly at $60^{\circ} \mathrm{C}$ and there are no significant differences $(\mathrm{P}<0.05)$ between phage titer in temperature $37^{\circ} \mathrm{C}$ and $40^{\circ} \mathrm{C}$ during the 60 minutes. And there was a significant differences between phage titer in temperature $37^{\circ} \mathrm{C}$ and $40^{\circ} \mathrm{C}$ during the $60 \mathrm{~min}$ in comparison with phage titer in temperature $50^{\circ} \mathrm{C}$ and $60^{\circ} \mathrm{C}$.

\section{DISCUSSION}

\section{ISOLATION AND IDENTIFICATION}

The importance of Staphylococcus aureus as a successful pathogen resides in its wide genetic diversity and host range and the different pathologies associated with infection. $S$. aureus is associated with hospital-acquired and community acquired infections and with human carriers (Miller and Diep, 2008) as well as livestock associated infections (Graveland et al., 2011), for which meticillin-resistant $S$. aureus (MRSA) and meticillin-sensitive S. aureus (MSSA) isolates are important pathogens (Hata et al., 2010).

In the present study, the identification of $S$. aureus isolates associated with bone infection in hospitals was investigated. Primary isolation and presumptive identification of the pathogen is crucial for microbiological diagnosis and epidemiological surveillance. In order to isolate and identify S. aureus a number of authors have used a variety of selective and/or differential culture media. Among the most common media used are salt-mannitol agar (SMA) and Staphylococcus-110 agar (S110), which are selective and differential media that take advantage of the tolerance of S. aureus to $7.5 \%(\mathrm{w} / \mathrm{v}) \mathrm{NaCl}$ as well as its metabolic activities, such as mannitol fermentation in SMA or gelatinase activity in S110 media.

Sheep's blood agar (SBA) is a rich medium in which the $\beta$ haemolytic activity of $S$. aureus isolates was clearly differentiated. In this current biochemical tests such as catalase, coagulase and oxidase tests used for identification of $S$. aureus.

As the use of differential and/or selective culture media for the isolation and primary identification of $S$. aureus isolates is not enough to ensure the identity of the isolates, a sec- 
ondary test is needed to precisely identify the isolates as $S$. aureus. Determinations of coagulase and $\beta$-haemolysin activities are easy and affordable confirmatory techniques to identify S. aureus. When one or both of these confirmatory tests were used in combination with each selective medium, they improved the ability to correctly identify S. aureus

For SBA, only the combination with coagulase test was presented because the criterion of $\beta$-haemolysis has been already considered in the positive colony morphology description, although $\beta$-haemolysis was confirmed again after primary isolation. All isolates were $\beta$-haemolytic. The use of coagulase at $24 \mathrm{~h}$ as a secondary test of identification improved sensitivity and specificity in combination with the respective culture medium. However, SMA and coagulase showed higher values of sensitivity compared with the other culture media. Using $\beta$-haemolysis as secondary test of identification also increased sensitivity, specificity when combined with the respective culture medium. Our results is confirmed with the work of (Bautista-Trujillo et al., 2013).

MSA is a selective as well as a differential media mannitol is the differential part, it indicates organisms that ferment mannitol. If mannitol fermentation is occurring, lactic acid will be produced, and the $\mathrm{pH}$ will drop causing the MSA medium to turn from red to yellow (with phenol red as $\mathrm{pH}$ indicator). The salt $(7.5 \%)$ portion is selective for members of the genus Staphylococcus (Benson, 2002); since they can tolerate high saline levels. Coagulase-positive staphylococci (COPS) will produce luxuriant growth of yellow colonies and may have a yellow halo around the colony. Coagulase-negative staphylococci (CONS) will produce small colourless to pink colonies with no colour change to the medium (Charles and Margi, 2002; Jakee et al., 2008).

Results of antimicrobial susceptibility test of $S$. aureus isolates revealed that all isolate were resistance to penicillin $100 \%$, this may explain why S. aureus is totally resistant to pencillin $\mathrm{G}$ which agreed with Al-Jundiy (2005), Zeidan (2005) and Al-Geobory (2011). The percentage of penicillin $\mathrm{G}$ resistant in these studies was $100 \%$, respectively. The present study results were compatible with results of Aghazadeh et al. (2009); likewise, this results were compatible with those obtained by Brady et al. (2007) as they observed that all isolates were resistant to penicillin and other $\beta$-lactam antibiotics.

It was found that $92.85 \%$ were resistant to cefoxitin and also $95.23 \%$ of $S$. aureus were resistant to methicillin. This result is close to work of Kalmus et al. (2011) and Deresse et al. (2012).

Infections due to MRSA are an increasing problem worldwide inside and outside of hospitals, it is clinically and epidemiologically important for laboratories to be able to differentiate MRSA from MSSA. Not only for choosing appropriate antibiotic therapy for the individual patient, but also for control of MRSA transmission (Boyce et al., 2005). Several groups of investigators have reported that the results of cefoxitin disk diffusion (DD) tests correlate better with the presence of mecA than do the results of disk diffusion tests using oxacillin (Swenson et al., 2005). Using cefoxitin and CLSI criteria for disc diffusion, the sensitivity and specificity for recognizing methicillin resistance were both $100 \%$ (Fernande et al., 2005).

Cefoxitin and moxalactam have been reported as surrogate markers for the detection of methicillin resistance (Felten et al., 2002; Skov et al., 2003). The NCCLS has recently reported cefoxitin zone diameter interpretive criteria for the prediction of mecA-mediated resistance (NCCLS, 2000).

\section{Isolation AND Purification of $S$. aureus}

\section{BACTERIOPHAGE}

Phage Isolation and Morphology: The common gold standard method for enumerating and differentiating phages is the double agar overlay assay. Therefore this current study are in agreement with (Mansura et al., 2015) in possibility of isolation of phage from sewage by using double agar overlay assay. Oot et al. (2007) emphasized the ubiquitous nature of phage populations, although bacteriophage counts can only rise after an increase in host bacteria population.

In studies involving dairy livestock, milk and udders were primary sources for samples from which phages were isolated (Brüssow and Desiere 2001; Garcia et al., 2007, 2009; Shi et al., 2010; Kwiatek et al., 2012). Alternate sources from which phages could be isolated include sewage or wastewater (Yoon et al., 2010), and feces (Oot et al., 2007; Niu et al., 2009; Santos et al., 2011).

Plaques were formed as clear circular with a size ranged between $2-3 \mathrm{~mm}$ in diameter when incubated at $37 \mathrm{Co}$ for $24 \mathrm{hrs}$. This result agreed with (Aidan et al., 2009; Longping and Zhiying, 2014) due to lyses of the bacterial host (MRSA). Sewage water was observed to be the best environmental source to get lytic phages with aggressive infective qualities; this might be attributed to the fact that phages from sewage tolerate hard conditions in the sewage; thus, these phages show high degree of lysis with high tolerance to harsh physical environment. Therefore, lytic phages from sewage showed larger plaques, higher titers, and clearer plaques than others.

This is in agreement with Marwa et al. (2014), they report that the different sources of phages' isolation and the finding that each phage showed unique profile of size, shape, clarity, and margin cut of plaques provided preliminary ev- 
idence that isolated phages are unique and no phages are identical to each other.

Preparation of Phage Stock and Titration: Agar overlay method was used for preparation of $S$. aureus phage stocks and obtain a titer between $10^{1}$ to $10^{9} \mathrm{PFU} / \mathrm{ml}$. this result was in agreement with (Iona and Mark, 2014). Which is achieved a titer in excess of $109 \mathrm{PFU} / \mathrm{ml}$.

From our results, the dilution factor gave the best countable number of plaques was $\left(10^{5}\right)$, this dilution factor was then used for all other experiments. In addition the optical density of all dilutions were recorded at the same time. The presence of these zones of clearing indicated that is, amplifying bacteriophage from a raw sewage sample and inoculating the phage into $S$. aureus host was an effective way of isolating and visualizing phage. Amplify (increase the numbers) of phages in the sewage sample by allowing them to infect and reproduce within fresh $S$. aureus, The infection then "spread" as the viruses reproduced and cells lyses, eventually forming a visible plaque the titer of a phage suspension, therefore, is determined by counting the number of plaques that form from a given volume of suspension. Phage titer is expressed as plaque forming units (PFU) per milliliter (ml), it was also determined at this stage which dilution factor gave the best countable number of plaques (Yoon et al., 2001).

\section{Determination of Host Range (Phage Typing)}

Spot test was used to determine the type of bacteriophage, MRSA isolates were successfully lysed by phage, forming a clear lyses zone and inhibition bacterial growth at the site of phage dropped. Approving these S. aureus isolates have specific receptor on its cell wall enabling phage to be attach, this is an agreement with Dias et al. (2013) and Longping and Zhiying (2014), which showed relatively wide spectrum host prophylaxis or treatment of $S$. aureus associated with osteomyelitis.

The specificity of phages for bacterial cells enables them to be used for the typing of bacterial strains and the detection of pathogenic bacteria. Phage typing is also known as the use of sensitivity patterns to specific phages for precisely identifying the microbial strains. For the detection of unknown bacterial strain its lawn is provided with different phages, and if the plaque (clear zones) appears then it means that the phage has grown and lysed the bacterial cell, making it easy to identify the specific bacterial strain (Clark and March, 2006).

Phage can be isolated from a wide variety of source such as sea water, sewage water/sludge etc. These phage feed mainly on locally available organisms and cell. They have an added advantage in that they are host specific and evolve a long with the host. The development of clear zones of lysis against $S$. aureus using specific phage lysate indicated that the phage we obtained in this experiment were lytic phage. Therefore this current study focused on the isolation of bacteriophage effective against MRSA, the main causative agent of osteomyelitis. Our results were in agreement with Mahadevan et al. (2009), who determined the host rage of the bacteriophage by (spot test) and they found that each of the tree virulent phages was able to independently lyse the original host bacterium.

\section{Minimum Inhibitory Concentration \\ BACTERIOPHAgE AGAINST MRSA}

Tube dilution tetrazolium assays (TTAs) have been used to probe the relationships between the cell survival, growth and differentiation that rely on the cellular reduction of tetrazolium salts to their intensely coloured formazans in mammalian cells (Scudiero et al., 1988; Marshall et al., 1995). This reagent has also been used effectively to differentiate between live and dead bacteria because only live bacteria convert the dye into an insoluble purple formazan measured at $560 \mathrm{~nm}$ (Stevens and Olsen, 1993). We adopted this method of quantifying dead bacteria by TT assay to estimate the MIC of phages. This adapted procedure is done for the first time in Iraq.

Antibiotic resistance amongst bacterial pathogens is a cause of widespread concern. Despite continuous and vigorous efforts, the discovery of new antibacterial has not kept pace with the requirements of the medical profession. Bacteriophage therapy, all but forgotten in the wake of the antibiotic era, has been attracting the attention of many research groups (Sulakvelidze et al., 2001) and efforts are being made to develop this naturally occurring agent into a preventive or therapeutic product. Virulent phages appear to be somewhat similar to antibiotics because they display remarkable antibacterial activity. Recent reports on the effects that such agents and their derivatives (Fischetti, 2010; Appaiah et al., 2012; Vipra et al., 2012) have on antibiotic resistant strains suggest a significant clinical advantage. Because a phage is a complex molecule and does not diffuse like an antibiotic, it is not possible to use a test similar to the disc diffusion test for this particular purpose.

In this study, we examined whether a test similar to the determination of minimum inhibitory concentration can be applied to phage preparations so that clinical laboratories might test the sensitivity of clinical isolates to identify the causative organism and future courses of action and treatment. Therefore, it is important to determine their concentrations quickly and reliably, and the proposed MIC method appears to be both reliable, and reproducible.

This method is laborious and time consuming, and the proposed MIC method appears to be an interesting alternative. In addition, one of the main factors affecting plaque 
formation is the density of the indicator cells on the plates, because a very dense confluent lawn would affect infection by phage, resulting in very small plaques (Rabbani et al., 2004). None of these factors affect the MIC method of detecting phage adsorption, which is novel, time-saving, easy and could even be applied to mammalian viruses for titer estimation (Goldberg et al., 1994). The TTA colorimetric bactericidal assays have been shown to produce comparable results with $S$. aureus, Salmonella, E. coli and Klebsiella (Vipra et al., 2013), supporting our observations regarding the applicability of this dye in measuring viability in MRSA. The MIC test can be conducted manually or it can be completely automated, depending on particular lab situations to handle several samples simultaneously. The MIC method could prove very useful in the diagnosis of bacterial strains through phage typing, and the results of this study determine the presence of prophages in any bacterial host, which is both novel and interesting.

\section{Effect of Temperature and pH on the Infectivity of Phage \\ $\mathrm{pH}$ values of 2, 7.4 and 8 were used to determine wheth- er the bacteriophage are affected by exposure to different $\mathrm{pH}$ values. The values were chosen in accordance with the range of $\mathrm{pH}(2-8)$ obtained in Rabbit GIT. Plaque assays were performed on every sample to register the change in abundance of infectious phages over time.}

The impact of bacteriophage treatment of bacterial pathogens in infected rabbits depends on the ability of the phages to reach the target organs at sufficient density and lytic potential to control the pathogen. Numerous factors affect the survival and lytic properties of the phages administered to the rabbits, e.g., delivery mechanism, multiplicity of infection, animal's immune response, physical and chemical environment, and development of phage-resistant bacteria. However, little is known about the fate of bacteriophages after addition to infected rabbits.

The aim of this experiment was to examine the regulation of bacteriophage survival/decay in controlled laboratory experiments at various environmental $\mathrm{pH}$ that influenced the decay rates of phage and the infectivity of the bacteriophage.

Our results in agreement with Jonczy et al. (2011), which they approved that some phage can be stored for a long period in neutral $\mathrm{pH}(6-8)$. This experiments testing the $\mathrm{pH}$ tolerance of the bacteriophages confirmed that the $\mathrm{pH}$ was very important for the infectivity of the phages.

The effect of temperature on the infectivity of phage was also evaluated. The temperature at which a phage loses viability is called thermal inactivation temperature. This loss of viability has been shown to result from disruption of head proteins and the subsequent release of DNA, and the alteration of phage binding receptors (adsorption sites) (Slopek et al., 1987). These results were in agreement to Al-khafaji (2012).

\section{CONCLUSION}

S. aureus was the most frequent isolated bacteria from bone infection in all age patients. Sewage water was observed to be the best environmental source to get lytic phages with aggressive infective qualities and the isolated phages show high degree of lysis with high tolerance to harsh physical environment such as $\mathrm{pH}$ and temperatures in vitro. The Tube dilution tetrazolium assays (TTAs) have been used first time in country to estimate the MIC of bacteriophage and it appears to be both reliable, and reproducible. This method is laborious and time consuming, and the proposed MIC method appears to be an interesting alternative.

\section{ACKNOWLEDGEMENT}

Authors acknowledges to the Department of Physiology and Pharmacology and Surgery, College of Veterinary Medicine, Baghdad University, Baghdad, Iraq.

\section{CONFLICT OF INTERESTS}

There exists no conflict of interest.

\section{AUTHORS' CONTRIBUTION}

All the authors have contributed equally in terms of giving their technical knowledge to frame the article.

\section{REFERENCES}

- Aghazadeh M, Rahbar M, Monnavar MK, Moghadam FS (2009). Sensitivity pattern of methecillin resistant and methicillin sensitive Staphylococcus aureus isolates, against several antibiotics including tigecycline in Iran: A hospital study. Pak. J. Med. Sci. 25: 443-446.

-Aidan JS, Ying K, Miki K, Keiko Y, Hidetomo I, Yasunori T (2009). Isolation from sewage influent and characterization of novel $S$. aureus bacteriophages with wide host ranges and potent lytic capabilities. Appl. Environ. Microbiol. 75: 4483- 4490. http://dx.doi.org/10.1128/AEM.02641-08

-Al-Dahbi AM, Al-Mathkhury HJ (2013). Distribution of methicillin resistant Staphylococcus aureus in Iraqi patients and healthcare worker. Iraqi J.Sci. 54: 293-300.

-A1-GeoboryHA (2011). Comparative study between Methicillin resistant Staphylococcus aureus (MRSA) and Methicillin sensitive Staphylococcus aureus (MSSA), and detect the antimicrobial effects of some plant extracts on them. M.Sc. thesis, College of Science, Baghdad University, Iraq.

-A1-Hasani HM (2005). Comparative Study between methicillinresistant coagulase positive and negative Staphylococci. M.Sc. Thesis, College of Science, University of Baghdad, Baghdad,Iraq.

-Al-Mussawi,Abdulameer A.(2014).Detection of Staphylococcus Aureus And Methicillin Resistant Staphylococcus Aureus 
(MRSA) From Human Clinical Specimens Using Conventional Biochemical Tests And Chromogenic Media. Ind. J. of Appl. Res. 4: 7-9.

-Alisky J, Iczkowski K., Rapoport A, Troitsky N (1998). Bacteriophages show promiseas antimicrobial agents. J. Infect. 36: 5-15. http://dx.doi.org/10.1016/S01634453(98)92874-2

-Al-Jundiy AS (2005). Immunological Study on TSS-1 toxin extracted from Staphylococcus aureus Isolated from infected wounds. Ph. D. thesis, College of Science, Al-Mustansyria University.

-Al-khafaji AM (2012). Identification and Characterization of staphylococcus aureus Phage Isolated from Sewage. AlQadisiya J. Vet. Med. Sci. 11: 34-41.

-Anderson B, Rashid MH, Carter C, Pasternack G, Rajanna C, Revazishvili T, Senecal A, Sulakvelidze A (2011) Enumeration of bacteriophage particles comparative analysis of the traditional plaque assay and real-time QPCR- and nanosight-based assays. Bacteriophage. 1: 86-93. http:// dx.doi.org/10.4161/bact.1.2.15456

-Anonymous (2012). Effects of antibiotics on animal feed. Available at: HYPERLINK "http://www.udel.edu/chem/ C465/senior/fall97/feed/present.html\%20accesssed\%20 on\%2029/11/2012" http://www.udel.edu/chem/C465/ senior/fall97/feed/present.html accesssed on 29/11/2012.

-Appaiah CB, Sudarson S, Anupama BR, Bharathi S, Padmanabhan S (2012). Staphylococcus bacteriophage tails with bactericidal properties: New findings. Biotechnol. Appl. Biochem. 59: 495-502. http://dx.doi.org/10.1002/bab.1052

-Ashelford KE, Norris SJ, Fry JC, Bailey MJ, Day MJ (2000). Seasonal population dynamics and interactions of competing bacteriophages and their host in the rhizosphere. Appl. Environ. Microbiol. 66: 4193-4199. http://dx.doi. org/10.1128/AEM.66.10.4193-4199.2000

-Babakir-Mina M, Othman N, Najmuldeen HH, Noori CK, Fatah CF,Perno C. Ciotti M (2012). Antibiotic susceptibility of vancomyin and nitrofurantoin in Staphylococcus aureus isolated from burnt patients in Sulaimaniyah, Iraqi Kurdistan. New Micro. 35: 439-446.

-Baron S, Peterson LR, Finegold SM (1994). Bailey and scoffs diagnostic microbiology, $9^{\text {th }}$ ed. The CV Mosby Co., USA. Pp. 386-403.

-Bautista-Trujillo GU, Solorio-Rivera JL, Renterı'a-Solo' RI, Carranza-Germa'n SI, Bustos- Martı'nez JA, ArteagaGaribay RI, Baizabal- Aguirre VM, Cajero-Jua'rez M, Bravo- Patiño A, Valdez Alarco'n JJ (2013). Performance of culture media for the isolation and identification of Staphylococcus aureus from bovine mastitis. J. Med. Microbiol. 62: 369-376. http://dx.doi.org/10.1099/jmm.0.046284-0

-Benson JH (2002). Microbiological applications: Laboratory manual in general microbiology $\left(8^{\text {th }} \mathrm{ed}\right)$. McGraw-Hill Higher Education, New York.

- Bogozova GG, Voroshilova NN, Bondarenko VM (1991). The efficacy of Klebsiella pneumoniae bacteriophage in the therapy of experimental Klebsiella infection. Zh. Mikrobiol. Epidemiol. Immunobiol. 4: 5-8.

-Borysowski J, Gorski A (2008). Is phage therapy acceptable in the immunocompromised host? Int. J. Infect. Dis. 12: 466471. http://dx.doi.org/10.1016/j.ijid.2008.01.006

-Boyce JM, Cookson B, Christiansen K, Hori S, VuopioVarkila J, Kocagöz S, Oztop AY, Vandenbroucke-Grauls CM, Harbarth S Pittet D (2005). Meticillin resistant Staphylococcus aureus. Lancet Infect. Dis. 5: 653-663. http:// dx.doi.org/10.1016/S1473-3099(05)70243-7

-Brady RA, Leid JG, Kofonow J, Costerton JW, Shirtliff ME (2007). Immunoglobulins to surface associated biofilm immunogens provide a novel means of visualization of methicillin-resistant Staphylococcus aureus biofilms. Appl. Environ. Microbiol. 73: 6612- 6619. http://dx.doi.

org/10.1128/AEM.00855-07

-Brüssow H, Desiere F (2001). Comparative phage genomics and the evolution of Siphoviridae: insights from dairy phages. Mol. Microbiol. 39: 213-222. http://dx.doi.org/10.1046/ j.1365-2958.2001.02228.x

- Charles M, Margi S (2002).Laboratory procedures for veterinary technicians, $4^{\text {th }}$ ed. Black Well Scientific Publication, Oxford, London. Pp. 136.

-Chambers HF (2001). The changing epidemiology of Staphylococcus aureus? Emerg Infect Dis; 7 (2). Pp: 178182.

- Chomel BB, Sun B (2011). Zoonoses in the Bedroom, Emerg. Infect. Dis. 17: 167-172.

- Clark JR, March JB (2006). Bacteriophages and biotechnology: vaccines, gene therapy and antibacterials. Trends Biotechnol. 24: 212- 218. http://dx.doi.org/10.1016/j. tibtech.2006.03.003

- CLSI (2012). Clinical Laboratory Standards Institute: Performance standards for antimicrobial susceptibility testing; Twenty-second informational supplement. CLSI document M100-S22, CLSI, Wayne, PA.

-Curtin JJ, Donlan RM (2006). Using bacteriophages to reduce formation of catheter associated biofilms by Staphylococcus epidermidis.Antimicrob.Agents Chemother.50:1268-1275. http://dx.doi.org/10.1128/AAC.50.4.1268-1275.2006

-Dabrowska K, Swita a-Jelen K, Opolski A, Weber-Dabrowska B, Gorski A (2005). Bacteriophage penetration in vertebrates. J. Appl. Microbiol. 98: 7-13. http://dx.doi.org/10.1111/ j.1365-2672.2004.02422.x

-Deresse D, Solomon G, Dawit Y (2012). Antibiotic-resistance Staphylococcus aureus isolated from cow's milk in the Hawassa area, South Ethiopia. Annls. Clin. Microbiol. Antimicro. 11: 1-6. http://dx.doi.org/10.5897/ajmr11.1615

-Dias R S, Eller MR, Duarte VS, Pereira ÂL, Silva CC, Mantovani HC, Oliveira LL, Silva E, de A.M, Paula, SO (2013). Use of phages against antibiotic-resistant Staphylococcus aureus isolated from bovine. J. Anim. Sci. 91: 3930-3939. http:// dx.doi.org/10.2527/jas.2012-5884

-Enright MC, Robinson DA, Randle G, Feil EJ, Grundmann $\mathrm{H}$ and Spratt BG (2002). The evolutionary history of methicillinresistant Staphylococcus aureus (MRSA). Proc Natl Acad Sci USA., 99: 7687-7692.

-EUCAST (2009). Breakpoint tables for interpretation of MICs and zone diameters. The European Committee on Antimicrobial Susceptibility Testing. http://www.eucast.org /fileadmin/src/media/PDFs/EUCAST_files/Disk_test_ documents/EUCAST_breakpoints_v1.0_20091221.pdf.

- Felten A, Grandry B, Lagrange PH, Casin I (2002). Evaluation of three techniques for detection of low-level methicillin resistant Staphylococcus aureus (MRSA) a disk diffusion method with cefoxitin and moxalactam, the Vitek 2 system, and the MRSA screen latex agglutination test. J. Clin. Microbiol. 40: 2766-2771. http://dx.doi.org/10.1128/ JCM.40.8.2766-2771.2002

- Fernande CJ, Lorna A, Fernandes, Peter Collignon. (2005). Cefoxitin resistance as a surrogate marker for the detection of methicillin-resistant Staphylococcus aureus. J. Antimicrob. Chemother. 55: 506- 510. http://dx.doi.org/10.1093/jac/ dki052

-Fischetti VA (2010). Bacteriophage endolysins: A novel antiinfective to control gram-positive pathogens. Int. J. Med. Microbiol. 300: 357-362. http://dx.doi.org/10.1016/j. ijmm.2010.04.002

-Flaherty JE, Jones JB, Harbaugh BK, Somodi GC, Jackson LE (2000). Control of bacterial spot on tomato in the greenhouse and field with h-mutant bacteriophages. Bioscience. 35: 882-888.

- Forrester A (2002). Patient self-cure chapter 22: Gastrointestinal conditions. Cand. Pharma. Assoc. Pp. 238-251.

-Freeman-Cook L, Freeman-Cook K (2006). Staphylococcus aureus infections. Chelsea house publishers, USA.

- García PC, Madera B, Martinez A, Rodríguez JE (2009). 
Prevalence of bacteriophages infecting Staphylococcus aureus in dairy samples and their potential as biocontrol agents. J. Dairy Sci. 92: 3019-3026. http://dx.doi.org/10.3168/ jds.2008-1744

- García PC, Madera B, Martínez A, Rodríguez A (2007). Biocontrol of Staphylococcus aureus in curd manufacturing processes using bacteriophages. Int. Dairy J. 17: 1232-1239. http://dx.doi.org/10.1016/j.idairyj.2007.03.014

- Gennari L, Di Stefano M, Merlotti D (2005). Prevalence of bone infection in Italy. J. Bone Miner. Res. 20: 1845-1850. http://dx.doi.org/10.1359/JBMR.050518

- Goldberg E, Grinius L, Letellier L (1994). Recognition, attachment and injection. In: Molecular biology of bacteriophage T4 (eds. Drake JW, Kreu-zer KN, Mosig G, Hall DH Eiserling FA), American Society for Microbiology, Washington DC.Pp. 347-356.

- Goode D, Allen VM, Barrow PA (2003). Reduction of ExperimentalSalmonellaand CampylobacterContamination of Chicken Skin by Application of Lytic Bacteriophages. Applied and Environmental Microbiology,.69: 5032-5036.

- Graveland H, Duim B, van Duijkeren E, Heederik D, Wagenaar A (2011). Livestock-associated methicillin-resistant Staphylococcus aureus in animals and humans. Int. J. Med. Microbiol. 301: 630-634. http://dx.doi.org/10.1016/j. ijmm.2011.09.004

-Hata EK, Katsuda K, Kobayashi H, Uchida I, Tanaka K, Eguchi M (2010). Genetic variation among Staphylococcus aureus strains from bovine milk and their relevance to methicillinresistant isolates from humans. J. Clin. Microbiol. 48: 21302139. http://dx.doi.org/10.1128/JCM.01940-09

-Hendrix RW (2002). Bacteriophages: evolution of the majority. Theoret. Popul. Biol. 61: 471-480. http://dx.doi. org/10.1006/tpbi.2002.1590

-Inchley CJ (1969). The activity of mouse Kupffer cells following intravenous injection of $\mathrm{T} 4$ bacteriophage. Clin. Exp. Immunol. 5: 173- 187.

-ICTV (2015). International Committee on Taxonomy of Viruses: Virus taxonomy. EC 47, London, UK, July 2015. www.ictvonline.org/virus taxonomy.asp.

-Iona HB, Mark DL (2014). Stress sensitivity assays of bacteriophages associated with Staphylococcus aureus, causal organism of bovine mastitis. Afr. J. Microbiol. Res. 8: 200-210. http://dx.doi.org/10.5897/AJMR2013.5877

-Jackson LC, Pacchiana PD (2004). Common complications of fracture repair. Clin. Tech. Small Anim. Pract. 19: 168-179. http://dx.doi.org/10.1053/j.ctsap.2004.09.008

- Jaime M, Tiffany F (2003). Isolation of E. coli bacteriophage. Phage Method. 2: 266-276.

- Jakee J, Ata S, Nagwa M, Bakry SA, Zouelfakar EE, Gad E1Said WA (2008). Characteristics of Staphylococcus aureus strains isolated from human and animal sources. AmEurasian J. Agric. Environ. Sci. 4: 221-229.

- Jonczy KE, Klak M, Miedzybrodzki R, Gorski A (2011). The influence of external factors on bacteriophages-review. Folia Microbiol. 56: 191-200. http://dx.doi.org/10.1007/s12223011-0039-8

-Kalmus P, Aasmäe B, Kärssin A, Orro T, Kask K (2011). Udder pathogens and their resistance to antimicrobial agents in dairy cows in Estonia. Acta. Vet. Scand. Vol 12: 53: 54.

-Kwiatek M, Parasion S, Mizak L, Gryko R, Bartoszcze M, Kocik J (2012). Characterization of a bacteriophage, isolated from a cow with mastitis that is lytic against Staphylococcus aureus strains. Arch. Virol. 157: 225-234. http://dx.doi. org/10.1007/s00705-011-1160-3

-Kysel DT, Turner PE (2007). Optimal bacteriophage mutation rates for phage therapy. J. Theoret. Biol. 249: 411-421. http:// dx.doi.org/10.1016/j.jtbi.2007.08.007

- Lee JH (2003). Methicillin (Oxacillin)-resistant Staphylococcus aureus strains isolated from major food animals and their potential transmission to humans. Appl. Environ. Microbiol. 69: 6489-6494.
- Leverentz B, Conway WS, Camp MJ, Janisiewicz WJ, Abuladze T, Yang M, Levison ME, Levison JH, (2009). Pharmacokinetics and pharmacodynamics of antibacterial agents," Infectious Disease Clinics of North America, 23: 791-815.

-Longping L, Zhiying Z (2014). Isolation and characterization of a virulent bacteriophage SPW specific for Staphylococcus aureus isolated from bovine mastitis of lactating dairy cattle. Mol. Biol. Rep, 41: 5829-5838. http://dx.doi.org/10.1007/ s11033-014-3457-2

-Madsen L, Sif KB, Inger D, Mathias M (2013). Dispersal and survival of Flavobacterium psychrophilum phages in vivo in rainbow trout and in vitro under laboratory conditions: Implications for their use in phage therapy. Appl. Environ. Microbiol. 79: 4853-4861. http://dx.doi.org/10.1128/ AEM.00509-13

- Mahadevan M, Sundar GS, Arijit SB, Sandeep S (2009). Isolation of host-specific bacteriophage from sewage against human pathogens. Asian J. Biotechnol. 1: 163-170. http:// dx.doi.org/10.3923/ajbkr.2009.163.170

- Maier MR, Pepper IL, Gerba C (2000). Environmental microbiology. Academic Press, USA. Pp. 491-500.

-Mansura S, Mulani SA, Shaikh A, Shilpa T (2015). Harnessing the power of bacteriophage for pathogen reduction in wastewater. Int. J. Curr. Microbiol. Appl. Sci. 2: 152-161.

-Marshall NJ, Goodwin CJ, Holt SJ (1995). A critical assessment of the use of micro-culture tetrazolium assays to measure cell growth and function. Growth Regul. 5: 69-84

- Marwa B, Sabri MS, Ahmed SA (2014). In vitro study on using bacteriophages in the treatment of pathogenic Escherichia coli in Iraq. Iraqi J. Med. Sci. 12: 131-138.

-Matsuzaki S, Rashel M,Uchiyma J,Ujihara T, Kuroda M,Ikeuchi M, Fujieda M, Wakiguchi J, Imai S (2005). Bacteriophage therapy: a revitalized therapy against bacterial infectious diseases. J. Infect. Chemother. 11: 211-219. http://dx.doi. org/10.1007/s10156-005-0408-9

-Mejìa C, Zurita J, Guzmn-Blanco M (2010). Epidemiology and surveillance of methicillinresistant Staphylococcus aureus in Latin America. Braz. J. Infect. Dis. 14: 79-86.

-Miller LG, Diep BA (2008). Clinical practice: colonization, fomites, and virulence: rethinking the pathogenesis of community associated methicillin-resistant Staphylococcus aureus infection. Clin. Infect. Dis. 46: 752-760. http:// dx.doi.org/10.1086/526773

- Morgan M (2008). Methicillin resistant Staphylococcus aureus and animals: zoonosis or humanosis? J. Antimicrob. Chemother. $62: 1181-1187$.

-Muhammad HA, Al-Mathkhury HJ (2014). The Prevalence of methicillin resistant Staphylococcus aureus and methicillin resistant Staphylococcus epidermidis in Al-Sulaimania city. Iraqi J. Sci. 55: 386-393.

-NCCLS (2000). National Committee for Clinical Laboratory Standards: Approved standard M7-A5: Methods for dilution antimicrobial susceptibility test for bacteria that grow aerobically, $5^{\text {th }} \mathrm{Ed}$.

-Niu YD, McAllister TA, Xu Y, Johnson RP, Stephens TP, Stanford K (2009). Prevalence and impact of bacteriophages on the presence of Escherichia coli O157:H7 in feedlot cattle and their environment. Appl. Environ. Microbiol. 75: 12711278. http://dx.doi.org/10.1128/AEM.02100-08

- Oot RA, Raya RR, Callaway TR, Edrington TS, Kutter EM, Brabban AD (2007). Prevalence of Escherichia coli O157 and O157:H7- infecting bacteriophages in feedlot cattle feces. Lett. Appl. Microbiol. 45: 445-453. http://dx.doi. org/10.1016/j.febslet.2007.10.009

-Park SC, Nakai T (2003). Bacteriophage control of Pseudomonas plecoglossicida infection in ayu Plecoglossus altivelis. Dis. Aquatic Organ. 53: 33-39. http://dx.doi.org/10.3354/ dao053033

- Provincial Infection Control Network of British Columbia (PICNet). (2016). Methicillin-resistant Staphylococcus 
aureus (MRSA) Update. Q2 of Fiscal Year 2015.

-Rabbani I, Radoja U, Ray S, Selim A, Weston C (2004). The dynamics of bacteriophage T4 binding to Escherichia coli. J. Exp. Microbiol. Immunol. 5: 61-64.

- Rayner C, Munckhof WJ (2005). Antibiotics currently used in the treatment of infections caused by Staphylococcus aureus. Intern. Med. J. 35: 3-16.

- Rich M, Roberts L (2004). Methicillin-resistant Staphylococcus aureus isolates from companion animals. Vet. Rec. 154: 310.

-Russell WJ, Taylor SA, Sigel MM (1976). Clearance of bacteriophage in poikilothermic vertebrates and the effect of temperature. J. Reticuloendothel. Soc. 19: 91-96.

-Sandeep K (2006). Bacteriophage precision drug against bacterial infections. Curr. Sci. 90: 361-363.

-Sanders ER (2012). Aseptic laboratory techniques: plating methods. Microbiology, immunology and molecular genetics, University of California, Los Angeles. http:// dx.doi.org/10.3791/3064

-Santos TM, Ledbetter EC, Caixeta LS, Bicalho ML, Bicalho RC (2011). Isolation and characterization of two bacteriophages with strong in vitro antimicrobial activity against Pseudomonas aeruginosa isolated from dogs with ocular infections. Am. J. Vet. Res. 72: 1079-1086. http:// dx.doi.org/10.2460/ajvr.72.8.1079

-SAS (2012). Statistical Analysis System, User's Guide. Statistical. Version 9.1th ed. SAS Inst. Inc., Cary NC, USA.

-Sadia S, Usmanghani K, Sheikh ZA, Zahoor A, Gul S (2015). In vitro evaluation of antimicrobial activity of Entoban Syrup: A polyherbal formulation. World J. Pharma. Res. 4: 504-511.

- Schultz I, Neva FA (1965). Relationship between blood clearance and viruria after intravenous injection of mice and rats with bacteriophage and polioviruses. J. Immunol. 94: 833-841.

-Scudiero DA, Shoemaker RH, Paull KD, Monks AS, Tierney TH, Nofziger MJ, Currens D. Seniff Boyd MR (1988). Evaluation of a soluble tetrazolium/for-mazan assay for cell growth and drug sensitivity in culture using human and other tumor cell lines. Cancer Res. 48: 4827-4833.

-Shasha SM, Sharon N, Inbar M (2004). Bacteriophages as antibacterial agents. Harefuah. 143: 121-125.

- Shi D, Hao Y, Zhang A, Wulan B, Fan X (2010). Antimicrobial resistance of Staphylococcus aureus isolated from bovine mastitis in China. Transbound. Emerg. Dis. 57: 221-224. http://dx.doi.org/10.1111/j.1865-1682.2010.01139.x

-Skov R, Smyth R, Clausen MA. Larsen RN, Frimodt-Møller B, Olsson-Liljequis, Kahlmeter G (2003). Evaluation of a $30 \mathrm{mg}$ cefoxitin disc on Iso-Sensitest agar for detection of methicillinresistant Staphylococcus aureus. J. Antimicrob. Chemother. 52: 204-207. http://dx.doi.org/10.1093/jac/ dkg325

-Slopek S, Weber-Dabrowska B, Dabrowski M, Kucharewicz K (1987). Results of bacteriophage treatment of supportive bacterial infections in the years 1981-1986. Arch. Immunol. Ther. Exp. Warsz. 35: 569-583.

- Sowmya N, Savitha S, Swapna Mallure K. Mohanakrishnan G, Sumathi P, Arumugam (2014). A two year study of spectrum of bacterial isolates from wound infections by aerobic culture and their antibiotic pattern in a tertiary care centre. Int J. Curr. Microbiol. App. Sci. 3: 292-295.

-Stenholm AR, Dalsgaard I, Middelboe M (2008). Isolation and characterization of bacteriophages infecting the fish pathogen Flavobacterium psychrophilum. Appl. Environ. Microbiol. 74: 4070-4078. http://dx.doi.org/10.1128/ aem.00428-08

- Stefani S, Chung DR, Lindsay JA, Friedrich AW, Kearns AM, Westh H, MacKenzie FM (2012). Meticillin-resistant Staphylococcus aureus (MRSA): global epidemiology and harmonisation of typing methods, Int J Antimicrob Agents. 39: 273-282.
- Stevens MG, Olsen SC (1993). Comparative analysis of using MTT and XTT in colorimetric assays for quantitating bovine neutrophil bactericidal activity. J. Immunol. Methods. 157: 225-231. http://dx.doi.org/10.1016/00221759(93)90091-K

-Sulakvelidze A, Alavidze ZG, Morris J Jr (2001). Bacteriophage therapy. Antimicrob. Agents Chemoth. 45: 649-659. http:// dx.doi.org/10.1128/AAC.45.3.649-659.2001

-Sulakvelidze A (2011). Safety by nature: potential bacteriophage applications. Microbial. 6: 122-126. http://dx.doi. org/10.1128/microbe.6.122.1

-Swenson JM, Fred C, Tenover, the Cefoxitin Disk Study Group (2005). Results of disk diffusion testing with cefoxitin correlate with presence of mecA in Staphylococcus spp. J. Clin. Microbiol. 43: 3813-3823. http://dx.doi.org/10.1128/ JCM.43.8.3818-3823.2005

-Uhr JW, Weissmann G (1965). Intracellular distribution and degradation of bacteriophage in mammalian tissues. J. Immunol. 94: 544-550.

-US Environmental Protection Agency's (EPA) (2001). Method 1601: Male-specific $(\mathrm{F}+)$ and Somatic Coliphage in Water by Two- Step Enrichment Procedure. EPA- 821-R-01- 030. Office of Water, Washington DC, USA.

- Vinodkumar CS, Kalsurmath S, Neelagund YF (2008). Utility of lytic bacteriophage in the treatment of multidrugresistant Pseudomonas aeruginosa septicemia in mice. Indian J. Pathol. Microbiol. 5: 360-366. http://dx.doi. org/10.4103/0377-4929.42511

-Vipra AA, Desai SN, Roy P, Patil R, Raj JM, Narasimhaswamy N, Paul VD, Chikkamadaiah R, Sriram B, (2012). Antistaphylococcal activity of bacteriophage derived chimeric protein P128. BMC Microbiol. 12: 41. http://dx.doi. org/10.1186/1471-2180-12-41

-Vipra A, Desai SN, Junjappa RP, Roy P, Poonacha N, Ravinder P, Sriram B, Padmanabhan S (2013). Determining the minimum inhibitory concentration of bacteriophages: Potential advantages. Adv. Microbiol. 3: 181-190. http:// dx.doi.org/10.4236/aim.2013.32028

-Wielders CL, Fluit S, Brisse J, Verhoef R, Schmitz FJ (2002). mecA Gene Is Widely Disseminated in Staphylococcus aureus Population. J. Clin. Microbiol. 40: 3970-3975.

-Weese JS, Archambault M, Willey BM, Hearn P, Kreiswirth BN, Said-Salim B, McGeer A, Likhoshvay Y, Prescott JF, Low DE (2005). Methicillin-resistant Staphylococcus aureus in horses and horse personnel, 2000- 2002. Emerg. Infect. Dis. 11: 430-435. http://dx.doi.org/10.3201/eid1103.040481

-Yocum RR, Waxman DJ, Rasmussen JR, Strominger JL (1979). Mechanism of penicillin action: penicillin and substrate bind covalently to the same active site serine in two bacterial D-alanine carboxypeptidases. Proc Natl Acad Sci.,76 : $2730-2734$.

-Yoon SJ, Choi YJ, Lee SY, Son JS, Jun SY, Kang SH (2010). Bacteriophage having killing activity specific to Staphylococcus aureus. US patent 8,071,352.

- Yoon SS, Kim JW,Breidt F, Fleming HP(2001). Characterization of a lytic Lactobacillus plantarum bacteriophage and molecular cloning of a lysine gene in Escherichia coli. J. Food Microbial. 65: 63-74. http://dx.doi.org/10.1016/S01681605(00)00498-0

-Zeidan IA (2005). Genetic and bacteriologic study to Staphylococcus aureus isolated from clinical specimens and resistant to Vancomycin antibiotic. M. Sc. Thesis, College of Science, Baghdad University.

-Zeller Vale'rie, Fre'de'rick D, Marie-Dominique K, Luc L, Jean-Marc Z, Patrick M, Nicole D (2009). Continuous cefazolin infusion to treat bone and joint infections: Clinical efficacy, feasibility, safety and serum and bone concentrations. Antimicrob. Agent Ch. 53(3): 883-887. http://dx.doi. org/10.1128/AAC.00389-08 